\title{
The Effect of Reporting Channel and Moral Reasoning on Intention to Report the Fraud in Procurement Processes in the Government Sector
}

\author{
Nayang Helmayunita ${ }^{1}$, Dian Fitria Handayani ${ }^{2}$ and Abel Tasman ${ }^{3}$ \\ ${ }^{1}$ Universitas Negeri Padang, Padang, Indonesia, e-mail: nayang.helma@gmail.com \\ ${ }^{2}$ Universitas Negeri Padang, Padang, Indonesia, e-mail: dianfitriahandayani@gmail.com \\ ${ }^{3}$ Universitas Negeri Padang, Padang, Indonesia, e-mail: abelltasman@gmail.com
}

\begin{abstract}
This study aims to examine the effect of the reporting channel and the level of moral reasoning on interest in reporting fraud that occurs in the procurement of goods / services in the government sector. In this study proposed the hypothesis that the interest to report fraud will be higher with the use of anonymous reporting channels as compared to using a non-anonymous reporting channel. In addition, people with high levels of moral reasoning will be more interested in reporting fraudulent actions than those who have low levels of moral reasoning. The study design was a laboratory experiment $2 \times 2$, with students accounting at Universitas Negeri Padang who has been at 5 and 7 semesters as employees of government agencies involved in the process of government procurement. Each subject is presented with one of two case versions available randomly. The statistical method used to test the hypothesis is two-way ANOVA. This study provides results that through an anonymous reporting channel, interest of employees to report any acts of fraud in the government procurement process will be higher than through non-anonymous reporting channels. Interest in reporting fraud in the government procurement process will be higher in individuals / employees who have higher levels of moral reasoning than individual employees with low levels of moral reasoning. When the available reporting channels are non-anonymous, individuals with a high level of moral reasoning will be more inclined to report fraudulent acts that occurred compared with individuals with low levels of moral reasoning.
\end{abstract}

Keywords: Reporting Channels, Moral Reasoning, Interest to report the fraud

\section{Introduction}

In 2007 the Institute of Business Ethics conducted a survey with the result that twenty-five percent of the organization's members were aware of the occurrence of violations, but those who knew more than half $(52 \%)$ did not report to more authorized parties. According to the KNKG (2008), reluctance to report violations can be minimized by the existence of an effective reporting system. Participation in the reporting system can be a response to provide information about indications of corruption (Winardi, 2013).

Several cases of corruption fraud that occurred were revealed due to reports provided by internal and external parties of the organization. Corruption cases that occurred inside the National Police were revealed by former Kabareskrim Susno Duadji, e-KTP cases and Hambalang revealed by Nazarudin, and cases of bribery in the election of Deputy Bank Indonesia were examples of cases revealed due to reports from outside parties or in the organization parties.

Realizing the fraud reports above, the existence of a reporting system (whistleblowing) is considered important. Because the reporting system is deemed effective in detecting fraud, most government agencies form a reporting system. With the existence of an effective system, it is expected that someone is encouraged to report any fraudulent actions that occur in an agency.

The results of Delloite's research cited by Albrech (2014: 453) state that many reporting systems do not work effectively due to lack of anonymity. Anonymous reporting system is believed to be more effective because this system can maintain the confidentiality of the reporter's identity. Because of the importance of this anonymity, the Sarbanes-Oxley Act of 2002 section 301 states that public company audit committees are required to create and supervise reporting channels for reporting 
anonymous employees regarding questionable accounting or audit issues. This indicates that the need for anonymous reporting channels strengthens internal controls related to fraud detection by ensuring that employees have access to reporting channels with relatively low personal costs.

The theory of hierarchy of needs expressed by Maslow (1954) states that every individual needs to feel safe. This will relate to the desire to report fraud. A reporting system that can guarantee the confidentiality of the reporter's identity will be a motivation for reporters to report because they feel that their basic needs are met.

According to Rotschild and Miethe (1999) whistleblowing can be viewed from two sides. First, whistleblowing is considered a form of betrayal because it has revealed the problems that exist within the organization. While the second, whistleblowing is considered positive because it has protected the values of truth which are considered more important than loyalty to the organization. This different view makes someone who will act to report the occurrence of fraudulent acts facing ethical dilemmas in deciding to reveal or allow the fraud to continue.

Based on the theory of planned behavior explains that someone will behave because of the intention. Therefore, the intention of a person has an important role in determining whistleblowing actions. The greater the strong intention to do, the greater the desire is carried out in the form of action. Besides that, one of the factors that can influence a person to become a whistleblower is the factor of morality. According to Kohlberg, based on the level of moral reasoning, everyone has certain reasons to act. In individuals who have a high level of moral reasoning, all actions carried out are not only motivated by personal gain but based on the law and applicable norms. Therefore, it can be said also that if there is an error or fraud in the organization, even though there is pressure in an organization not to report errors, rational and moral people will withstand such pressure, regardless of perceived retaliation, because moral is requirement for do it.

Large Literatures seek the factors that influence a person to report an act of fraud, including Kaplan \& Whitecotton (2001) about the responsibility of reporting, personal cost of reporting, and the severity of the violation. Curtis (2006) look for personal costs, while Liyanarachchi and Newdick (2009) are about moral reasoning and retaliation. Winardi (2013) regards to the status of perpetrators of fraud, materiality of fraud, and perception of retribution received. Bagustianto and Nurkholis (2015) are about the level of seriousness of fraud, personal costs, and organizational commitment. Kaplan and Schultz (2007) regards to internal quality and anonymous violation reporting channels.

This study examines factors that can influence a person's intention to report fraud that occurs in the procurement of goods and services. This is due to the many corruption frauds that occur and the disclosure of fraud due to the parties reporting. This study examines a person's intention to report based on hierarchical theory and moral reasoning theory. According to Maslow's hierarchical theory, one of the basic needs of a person is the guarantee of security. With the existence of an anonymity reporting system, it will be able to guarantee the security of potential reporters of fraud. This will cause the prospective reporter to decide to report fraud he / she knows to the authorities. According to the theory of moral reasoning, the level of one's moral reasoning will affect the individual in doing. At the lowest level of moral reasoning, individuals will act if the action will benefit themselves even if the action may not comply with the norms. While individuals who are at a high level of moral reasoning, individuals will act in accordance with the prevailing norms, even though the actions that must be taken do not guarantee personal security.

Based on the above formulation, the study aims to determine (1) whether the type of reporting channel will affect the interest to report on acts of fraud in the government procurement process? (2) Does the level of moral reasoning affect the interest to report fraud in the government procurement process. Theory of planned behavior (TPB) is a psychological theory that explains the relationship between attitudes and behavior. Based on this theory, a person's intention is more accurate to predict actual behavior. Thus, the intention will be an important factor to suspect the reporting action that will be carried out by a person. Ajzen (1991) assumes that intention can be a motivational factor that will influence a behavior that is shown through individual's effort is to realize into action. 
Ajzen (1991) uses three determinants namely normative beliefs, basic beliefs known as behavioral beliefs, and control beliefs. The concept of intention has three independent determinants. The first determinant is attitude towards behavior; in this stage, someone evaluates his behavior to be good to do or not. The second determinant is subjective norms, this determinant refers to the perception of perceived social pressure to consider doing a behavior. The third determinant is perceived behavioral control, referring to the ease or difficulty faced to conduct behavior. The better subjective attitudes and norms respond to behavior and the greater the perception of behavior control, then the stronger the individual's intention to consider implementing behavior.

Needs hierarchy theory was first proposed by Abraham Maslow in 1954. This theory is the most famous classical motivation theory and is still referred to by studies in certain fields. In this hierarchy of needs theory, Maslow stated that there were five basic needs needed by humans, namely:

a) Physiological needs, is the basic needs of everyone in the form of food and drink needs to survive

b) The need for security is the need for protection from harm physically and psychologically

c) Social needs are the need for recognition as members of social groups.

d) The need for appreciation is including as internal reward factors such as self-achievement and external reward factors such as status recognition

e) The need for self-actualization is the need to develop the potential as high as possible

Whistleblowing system is aimed to disclose violations, or unlawful, unethical or immoral acts committed by employees or organizational leaders to the authorities (internal or external), for the realization of ethical business practices in realizing good governance and clean government. Complaints from whistleblowers proved to be more effective in uncovering fraud than other methods such as internal audit or external audit (Sweeney, 2008 in Bagustianto, 2014).

Becoming a whistleblower is not an easy matter because the whistleblower will face an ethical dilemma between having to report or let the fraud remain hidden (Bagustianto, 2014). This is a big challenge for the reporting party, because it is likely that he will be considered a traitor and has violated the norms of organizational loyalty. Therefore, protection for whistleblowers must be of special concern. This is necessary to increase the desire of each party to report fraud in the organization.

The number of cases related to fraud that occur in the procurement of government goods and services is a strong indication that the prevention and detection of fraud in the procurement of goods and services has not been effective. Albrech et.al (2014: 435) has stated that there are two fundamental factors in preventing corruption. First, by creating a conducive work climate, and a culture of honesty of support to employees. Secondly, by eliminating opportunities to commit fraud and provide the right legal back feed for corruptors. Furthermore, Albrech also stated that one of the steps to eliminate the opportunity to commit fraud is creating a whistleblowing system.

In 2008, Park et.al divide the reporting system into several types. They are non-anonymous reporting channels and anonymous reporting channels. A non-anonymous reporting channel is a reporting channel that requires the complainant to convey his identity as a reporter that there is an act of corruption. While anonymous reporting channels are reporting channels that do not require the existence of an identity from the reporting party of corruption activities. In this channel system, reporters can report acts of corruption that occur in their organization without the need to include their identity.

Several previous studies provide results that this type of reporting channel will affect the interest of the person to report any act of corruption in the organization. Albrecht et.al (2004) state that anonymity is necessary for maintaining the confidentiality of the complainant's identity. Furthermore, Kaplan and Schults (2007) stated that the existence of non-anonymous reporting channels can reduce the desire to report corruption. This is because in the reporting system which is non-anonymity, the reporter who reports an act of corruption of his identity will be known by other members of the organization including the perpetrators of fraud, so that the reporter must be prepared with 
consequences such as might be considered a traitor within the organization, or consequences in the form of retaliation by the perpetrator.

Consequences that might be accepted by employees who report acts of corruption through nonanonymity reporting channels can create a dilemma for prospective reporters. Thus, it can reduce the interest of employees who know fraudulent actions to report it. Employees who know of acts of corruption will be afraid to report because they are not ready for the possibility of being threatened with retribution from perpetrators of fraud. This causes the loss of security needed by the prospective reporter. In fact, the need for a sense of security is a basic need that is needed by individuals as on Maslow's hierarchy of needs (1954).

In increasing the interest of employees to report corruption actions and eliminate acts of fraud or corruption in the government procurement process, it is necessary to have a reporting system that can accommodate them. The reporting system in this study is an anonymous reporting system. Allegations that in the anonymous reporting system employee interest in reporting suspected fraud will be higher than non-anonymous reporting channels. Based on this opinion, the first hypothesis proposed is:

H1: Through an anonymous reporting channel, employee interest in reporting fraudulent actions in the government procurement process will be higher than through non-anonymous reporting channels. Kohlberg (1969) made an important contribution to the theory of moral development by continuing Piaget's theory that had never been completed. Kohlberg's research shows the moral development of universal development. Kohlberg makes a sequence that defines a series of cognitive levels and is somewhat like stairs. In each of the three levels of ethical assessment, there are two stages of development, resulting in a total of six conditions as follows:

Pre-Conventional Level:

Stage 1: Compliance with rules and authority, avoid penalties, and do not do physical damage

Stage 2: Serving someone's needs or other people's needs and make a fair agreement in terms of concrete exchanges.

Conventional Level:

Stage 3: Play good roles, worry about others and their feelings, maintain loyalty and trust with partners, and motivate to follow rules and expectations.

Stage 4: Perform one's duties in the community, uphold social order, and maintain the welfare of the community or group.

Post-Conventional Level:

Stage 5: Enforcing basic rights, values, and public law contracts, even when they have conflicted with the laws and regulations of the group concrete.

Stage 6: Assuming guidelines based on universal ethical principles that must be followed by all humans (Kohlberg, 1981)

For pre-conventional people, the resolution of ethical dilemmas is only based on the cost and benefits of ethical action. For conventional people, the resolution is based on avoidance of danger to other people included in one's social institution. Post-conventional people frame ethical judgments based on internalized and self-selected principles. In Kohlberg's theory it is stated that the stage of the system of thought is organized in an organized manner and this is a series of invariant developments. The stages come one by one and in the same order and are hierarchical. Research on ethical reasoning in the accounting and auditing professions is important because the concept of professional ethics is more than just an external measure where the profession maintains a "pious image" (Ponemon et al. 1991). The process of ethical reasoning is part of the overall moral awareness of individuals in the face of difficult conflicts or dilemmas in daily practice.

This study is looking for relationship between moral reasoning and the whistle-blowing phenomenon. Whistle blowing is defined as "the disclosure by members of the organization (former and present) about the existence of illegal, immoral, or illegal practices under the control of their superiors, to people or organizations that may be able to take action" (Near and Miceli 1985). Research conducted by Arnold and Ponemon (1991) show that internal auditors with relatively low levels of moral 
reasoning tend not to report fraud, and this is especially true if there is potential retaliation. This finding is supported by Kohlberg's (1969) theory that individuals with lower levels of moral reasoning will make the decision to do the right thing to avoid punishment (stage 1) or to serve their own interests (stage 2).

If the individual is in the pre-conventional stage (stage 1 and stage 2), knowing the fraudulent actions that occur and the possibility of retaliation from the perpetrators of fraud, the individual tends to make more selfish decisions, so the choices to be made are likely to be not to disclose fraud. Whereas individuals who are in the conventional stage, when faced with the circumstances of fraud that occur within the organization, will be more likely to see in advance whether the action is common or not, if the fraud is common, the individual will not report, because it uses the assumption that this is a common thing in the organization.

In contrast to individuals who are in the post-conventional stage, they have had internalized ethical judgments on the individual. So, the decision to be taken is not a decision that only benefit themselves, but the decisions that really fit with the existing rules and norms. If an individual or employee who has a high level of moral reasoning is in a situation of knowing there is an act of fraud, the decision to be taken is to report the perpetrator of fraud to the authorities, even though there is a possibility of getting threats from the perpetrators of fraud.

Based on the description above, the next hypothesis proposed is:

$\mathrm{H} 2$ : The intention to report acts of fraud in the government procurement process will be higher in individuals / employees who have a higher level of moral reasoning than individual employees with a low level of moral reasoning.

H3: When the available reporting channels are non-anonymous, individuals with a high level of moral reasoning will be more likely to report fraud that occurs compared to individuals with low levels of moral reasoning.

\section{Research Methodology}

Subjects in this study were 5th semester UNP students, subjects were selected as proxy of employees in the regional government agencies involved in the procurement of goods and services.

This research was conducted through a $2 \times 2$ between subject design experiments. The experiment was designed by doing two treatments in two different conditions, namely the moral level (high / low) and the condition of non-anonymous and anonymous reporting channels.

Each subject is randomly placed into one of the treatment conditions. So, each subject receives one of the possible manipulation combinations distributed in two case versions, and with the same number of distributions from each version. It is expected that this will result in the number of subjects for each combination of the same experimental treatment. Table 1 presents the experimental design. Two cases designed are the first case of a combination of anonymous reporting channel manipulations. The second case is the manipulation of non-anonymous reporting channels.

Table 1. Research Design $2 \times 2$

\begin{tabular}{|c|l|c|c|}
\hline \multicolumn{2}{|c|}{ Treatment } & \multicolumn{2}{c|}{ Reporting Channel } \\
\cline { 3 - 4 } Moral Reasoning & high & case 1 & case 2 \\
\cline { 2 - 4 } & low & case 3 & case 4 \\
\hline \multirow{2}{*}{ Monymous } & \\
\hline
\end{tabular}

Subjects filled out a background questionnaire designed to gather demographic, educational and work information before working on experimental tasks. After completing the filling in of the participant's data, the subject is briefed on the case and then does the assignment and answers the questions in the case as well as the manipulation check questions. 
For reporting channels variable and intention to report fraud variable, this research instrument refers to research conducted by Kaplan et.al (2012) and Akbar (2016), with several adjustments related to the context of this study. This research instrument uses two cases.

For moral reasoning variables, this instrument is in the form of an ethical dilemma. Individual morality is measured through an instrument developed from Rest (2000) to measure the level of individual moral reasoning through four ethical dilemma scenarios. Each scenario is followed by twelve statements representing the Kohlberg 2-6 stage. After giving an assessment of the considerations in the twelve statements, participants were asked to rank 4 statements that were most important to them in making decisions. The four statements are then matched with their previous answers on the consideration of twelve statements. The score is given for each statement that matches stage 5-6. The calculation results of stage 5 and 6 are P-scores (post-conventional scores) which represent the level of individual moral reasoning. The P-score is calculated by adding each score from all four scenarios and dividing it by 0.40 .

To test hypothesis 1, 2, and 3 the data analysis technique used is variance analysis, two-way ANOVA

\section{Result and Discussion}

Manipulation Checks and Validation DIT. Experiments in this study were conducted six times with a total number of participants as many as 167 people. The results of the first phase analysis, namely the results of the manipulation check analysis show that out of 167 participants, only 125 participants passed the manipulation check. So that participants who did not pass the manipulation check were 42 people. This is because participants are wrong in interpreting the statement, so choosing the statements that they consider most "ideal", is not a statement describing the situation and conditions in their respective cases. While in the second analysis phase, namely the results of the DIT internal validity test analysis, there were 7 people who did not pass the DIT internal validity check because they did not complete all the tasks carried out in the DIT instrument.

Descriptive Statistics. Demographic characteristics of the participants illustrate that most of the participants were women $(68.64 \% \%)$. Besides that, it can also be seen that most participants are in semester 7 (60.10\%).

Based on the results of data processing, it is known that the maximum value of P-score is 57 while the minimum value is 2 . The cut-off value to determine the level of high or low moral reasoning is used median value (Ponemon, 1992). The median value of P-score is 15.00. Participants who have a P-score above 15.00 are grouped as participants who have a high level of moral reasoning, while participants who have a P-score below 15.00 are grouped as participants who have a low level of moral reasoning.

Hypothesis Testing. Before testing the hypothesis, the normality test is firstly carried out. The test results of normality with the Kolmogorov-Smirnov Test showed value of Asymp. Sig is 0.148, this value is above the value of 0.05 . So, it can be said that the data is normally distributed so that it meets one of the assumptions of analysis of variance (ANOVA).

Test of homogeneity of variance is also done to find out whether the four groups (groups 1,2,3, and 4) have the same variant. The results of statistical tests show the value of the Levene test statistic is 0.994 far above 0.05 . This shows that each subject group meets the same variant so that it has fulfilled the ANOVA assumption.

The next assumption that must be done is testing the analysis of variance-between groups. Based on the results of statistical tests, it is known that the p-value is significant at 0.002 , with a calculated $F$ value of 5.236. These results indicate that there are significant differences between groups. In table 2 it is also used to test hypotheses 1,2 and 3. 
Table 2. Tests of Between-Subjects Effects (Dependent Variable: Intention to report)

\begin{tabular}{|c|c|c|c|c|c|c|}
\hline Source & $\begin{array}{c}\text { Type III Sum } \\
\text { of Squares }\end{array}$ & df & $\begin{array}{c}\text { Mean } \\
\text { Square }\end{array}$ & F & Sig. & $\begin{array}{c}\text { Partial Eta } \\
\text { Squared }\end{array}$ \\
\hline Corrected Model & $91.448^{\mathrm{a}}$ & 3 & 30.483 & 5.236 & .002 & .121 \\
Intercept & 2881.494 & 1 & 2881.494 & 494.934 & .000 & .813 \\
RC & 24.693 & 1 & 24.693 & 4.241 & .042 & .036 \\
M & 43.406 & 1 & 43.406 & 7.456 & .007 & .061 \\
RC * M & 28.078 & 1 & 28.078 & 4.823 & .030 & .041 \\
Error & 663.705 & 114 & 5.822 & & & \\
Total & 3606.000 & 118 & & & & \\
Corrected Total & 755.153 & 117 & & & & \\
\hline
\end{tabular}

a. R Squared $=, 121$ (Adjusted R Squared $=, 098$ )

b. Computed using alpha $=, 05$

The research hypothesis (H1) predicts that through anonymous reporting channels, employee interest in reporting fraudulent actions in government procurement processes will be higher than through nonanonymous reporting channels. The result in table 2 shows that the significance value is 0.042 with an $\mathrm{F}$ value of 4.241. So, it can be concluded that between anonymous and non-anonymous reporting channels have significant differences in employee interest in reporting fraudulent actions in the government procurement process or the research hypothesis (H1) is accepted.

The research hypothesis (H2) predicts that interest in reporting fraud in the government procurement process will be higher for individuals / employees who have higher levels of moral reasoning than individuals / employees with low levels of moral reasoning. The result of testing the data in table 2 shows that, the significance value is 0.007 with an $\mathrm{F}$ value of 7,456. So, it can be concluded that between individuals / employees who have high moral reasoning will choose to report fraud that occurs compared to employees who have a low level of moral reasoning. This means that the research hypothesis (H2) is accepted.

The research hypothesis (H3) predicts that when the available reporting copy is non-anonymous, individuals with a high level of moral reasoning will be more likely to report fraud that occurs than individuals with low levels of moral reasoning. The result of testing the data in table 2 shows that, the significance value is 0.030 with an $F$ value of 4.823 . So, it can be concluded that when the available reporting channels are non-anonymous, individuals with a high level of moral reasoning will be more likely to report fraud that occurs compared to individuals with low levels of moral reasoning. This means that the research hypothesis (H3) is accepted.

This study proposes three hypotheses. The first hypothesis assumes that through an anonymous reporting channel, employee interest in reporting fraud in government procurement processes will be higher than through non-anonymous reporting channels. Based on the results of statistical tests, this hypothesis can be supported. So, the results of this study are in line with the Needs Hierarchy Theory which was discovered by Maslow (1954) as followed in Robbins (2008: 223). The results of this study also support the results of research conducted by Albrech (2004) and Kaplan and Schults (2007) which state that anonymity is necessary to maintain the confidentiality of the reporter's identity. Consequences that might be accepted by employees who report acts of corruption through nonanonymity reporting channels can create a dilemma for prospective reporters, so that it can reduce the interest of employees who know fraudulent actions to report it. Employees who know of acts of corruption will be afraid to report because they are not ready for the possibility of being threatened with retribution from perpetrators of fraud. This causes the loss of security needed by the prospective 
reporter. Even though the need for a sense of security is a basic need that is needed by individuals according to Maslow's hierarchy of needs (1954).

The second hypothesis predicts that interest in reporting fraud in the government procurement process will be higher in individuals / employees who have a high level of moral reasoning than individual employees with low levels of moral reasoning. Whereas the third hypothesis predicts when the available reporting copy is non-anonymous, individuals with a high level of moral reasoning will be more likely to report fraud that occurs than individuals with low levels of moral reasoning.

This study supports the results of research by Arnold and Ponemon (1991) showing that internal auditors with a relatively low level of moral reasoning tend not to report fraud, and this is especially true if there is potential retaliation. In addition, Kohlberg's (1969) theory states that individuals with lower levels of moral reasoning will make the decision to do the right thing to avoid punishment (stage 1) or to serve their own interests (stage 2).

If the individual is in the pre-conventional stage (stage 1 and stage 2), knowing the fraudulent actions that occur and the possibility of retaliation from the perpetrators of fraud, the individual tends to make more selfish decisions, so the choices to be made are likely to be not to disclose fraud. Whereas individuals who are in the conventional stage, when faced with the circumstances of fraud that occur within the organization, will be more likely to see in advance whether the action is common or not, if the fraud is common, the individual will not report, because it uses the assumption that this is a common thing in the organization. So, this supports the results of research that individuals with high levels of moral reasoning are more likely to report cheating that occurs than individuals with lower levels of moral reasoning.

Post-conventional stages are stages in which ethical assessment has been internalized in the individual. So that at this stage the decision to be taken is not a decision that only benefits yourself, but a decision that is truly in accordance with the existing rules and norms. This will cause the individual who is at this stage will decide to comply with the norms and rules that apply even when facing an unfavorable situation for his own self. This is consistent with the results of a study which states that when the available reporting copy is non-anonymous, individuals with a high level of moral reasoning will be more likely to report fraud that occurs than individuals with low levels of moral reasoning.

\section{Conclusion}

Based on the results of the analysis that has been carried out, it can be concluded that: (1) Through an anonymous reporting channel, employee interest in reporting fraud in the government procurement process will be higher than through non-anonymous reporting channels. (2) Interest in reporting fraud in the government procurement process will be higher in individuals / employees who have higher levels of moral reasoning than individual employees with low levels of moral reasoning. (3) When the available reporting copy is non-anonymous, individuals with a high level of moral reasoning will be more likely to report fraud that occurs than individuals with low levels of moral reasoning.

This study contained several limitations that could not be avoided and could influence the results of the study. These limitations are (1) the number of participants who did not pass the manipulation check in this study. This is suspected that they give less attention to the cases given, so their response becomes untouchable. (2) The case in this experiment is presented in the form of an illustration which is a simplification of the situation and conditions in the real world. So that the cases presented in the experimental instruments have not fully reflected the cases that occurred in the field.

Based on existing limitations, further research is expected to consider the following matters to show an increase in ecological similarity to the actual situation, then for future research it is better to use government officials as participants. In addition, the case of accounting fraud in research instruments can be redesigned again, so that it is more in line in the real situation. Subsequent research can also examine other aspects of the phenomenon of the desire to report accounting fraud that occurs by including variables related to the psychological or demographic aspects of respondents. 


\section{References}

Ajzen, I. (1991). The Theory of Planned Behaviour. Organizational Behaviour and Human Decision Processes, 179-221.

Akbar, T., Yonnedi, E., \& Suhernita. (2016). Pengaruh Saluran Pelaporan Pelanggaran dan Personal Cost terhadap Minat Untuk Melaporkan Kecurangan pada Pengadaan Barang/Jasa Pemerintah. Simposium Nasional Akuntansi XIX. Medan.

Albrecth, C. C., Zimbelman, M. F., Albrecth, W., \& Albrecth, C. O. (2014). Akuntansi Forensik: Forensic Accounting. Jakarta: Salemba Empat.

Arnold, D. F., \& Ponemon, L. A. (1991). Internal auditors' perceptions of whistle-blowing and the influence of moral reasoning: an experiment. Auditing: A Journal of Practice \& Theory, 1-15.

Bagustianto, R., \& Nurkholis. (2015). Faktor-Faktor Yang Mempengaruhi Minat Pegawai Negeri Sipil (PNS) Untuk Melakukan Tindakan Whistle-Blowing (Studi Pada PNS BPK RI). Simposium Nasional Akuntansi 18. Medan.

Bouville, M. (2008). Whistle-Blowing and Morality. Journal of Business Ethics, 579-585.

Curtis, M. B. (2006). Are Audit-related Ethical Decisions Dependent upon Mood? Journal of Business Ethics, 191-209.

Dozier, J. B., \& Miceli, M. P. (1985). Potential Predictors of Whistle-Blowing: A Prosocial Behavior Perspective. Academy of Management Review, 823-836.

Elias, R. (2008). Auditing students' professional commitment and anticipatory socialization and their relationship to whistleblowing. Managerial Auditing Journal , 283-294.

Ghozali, I. (2008). Desain Penelitian Eksperimental: Teori, Konsep dan Analisis Data dengan SPSS 16.0. Semarang: Universitas Diponegoro.

Hardjapamekas, E. R. (2008). http://www.fokal.info/fokal/arsip-hukum/365.html. Retrieved January 30, 2018, from fokal.info: http://www.fokal.info/fokal/arsip-hukum/365.html.

Helmayunita, N. (2018). The Influence of Personal Cost of Reporting, Organizational Commitment, Fraud Seriousnesss Level, and Gender to Intentions of Whistle-blowing. Padang 1st International Conference On Economics Education, Economics, Business and Management, Accounting and Entrepreneurship (PICEEBA 2018) (pp. 42-49). Padang: Atlantis Press.

Instruksi Presiden Republik Indonesia Nomor 17 Tahun 2011. (2011). Tentang Aksi Pencegahan dan Pemberantasan Korupsi Tahun 2012. Jakarta.

Instruksi Republik Indonesia Nomor 5 Tahun 2004. (2004). Tentang Percepatan Pemberantasan Korupsi. Jakarta.

K. N. (2008). Pedoman Sistem Pelaporan Pelanggaran-SPP (Whistle-Blwoing System-WBS). Jakarta. K. N. (2008). Pedoman Sistem Pelaporan Pelanggaran-SPP (Whistle-Blwoing System-WBS). Jakarta.

Kaplan, S. E., \& Schultz, J. J. (2007). Intentions to Report Questionable Acts: An Examination of the Influence of Anonymous Reporting Channel, Internal Audit Quality, and Setting. Journal of Business Ethics, 109-124.

Kaplan, S. E., \& Whitecotton, S. M. (2001). An Examination of Auditors' Reporting Intentions When Another Auditor is Offered Client Employment. Auditing A Journal of Practice \& Theory, 4563.

Kaplan, S. E., Pany, K., Samuels, J., \& Zhang, J. (2012). An Examination of The Effects Of Procedural Safeguards on Intentions to Anonymously Report Fraud. Advances In International Accounting , 88-95.

Khabibi, I. (2015, July 07). http://news.detik.com/berita/2962959/ini-mungkin-bukti-ahok-predikatwtp-dari-bpk-tak-jamin-bebas-korupsi. Retrieved January 30, 2018, from detiknews.com: http://news.detik.com/berita/2962959/ini-mungkin-bukti-ahok-predikat-wtp-dari-bpk-takjamin-bebas-korupsi

Kohlberg, L. (1969). Stage and Sequence: The Cognitive-Development Approach Moral Action to Socialization. Chicago: RandMcNally. 
Liyanarachchi, G., \& Newdick., C. (2009). The Impact of Moral Reasoning and Retaliation on Whistle-Blowing: New Zealand Evidence. Journal of Business Ethics, 37-57.

Nahartyo, E. (2012). Desain Dan Implementasi Riset Eksperimen. Yogyakarta: UPP STIM YKPN.

Near, J. P., \& Miceli, M. P. (1986). Organizational Dissidence: The Case of Whistle-Blowing. Journal of Business Ethics, 1-16.

Oktaresa, B. (2015, April 16). http://tatakelola.co/opini/korupsi-penyakit-yang-harus-dicegahdengan-imunitas-organisasi/. Retrieved January 31, 2018, from tatakelola.co: $\mathrm{http} / / /$ tatakelola.co/opini/korupsi-penyakit-yang-harus-dicegah-dengan-imunitas-organisasi/

Park, H., \& Blenkinsopp, J. (2009). Whistleblowing as Planned Behaviour - A Survey of South Korean Police Officer. Journa ofl Business Ethics , 545-556.

Park, H., Blenkinsopp, J., Oktem, M., \& Omurgonulsen, U. (2008). Cultural Orientation and Attitudes Toward Different Forms of Whistleblowing: A Comparison of South Korea, Turkey, and the U.K. Journal of Business Ethics, 929-939.

Peraturan Pemerintah Republik Indonesia Nomor 71 Tahun 2000. (2000). Tata Cara Pelaksanaan Peran Serta Masyarakat dan Pemberian Penghargaan dalam Pencegahan dan Pemberantasan Tindak Pidana Korupsi. Jakarta: Tambahan Lembaran Negara Republik Indonesia Nomor 3995.

Peraturan Presiden Republik Indonesia Nomor 4 Tahun 2015. (2015). Perubahan Keempat Atas Peraturan Presiden Nomor 54 Tahun 2010 Tentang Pengadaan Barang/Jasa Pemerintah. Jakarta: Lembaran Negara Nomor 5 Tahun 2015.

Putri, C. M. (2012). Pengujian Keefektifan Jalur Pelaporan Pada Structural Model Dan Reward Model Dalam Mendorong Whistleblowing: Pendekatan Eksperimen. Simposium Nasional Akuntansi 15. Banjarmasin.

Report To The Nations. (2014). On Occupational Fraud And Abuse 2014. Association of Certified Fraud Examiners.

Rest, J. R., Narvaez, D., Thoma, S. J., \& Bebeau, M. J. (2000). A Neo-Kohlbergian Approach To Morality Research. Journal of Moral Education , 381-395.

Sarbanes-Oxley Act Section 301. (2002). Public Law 107-204 July 30. USA: Sarbanes-Oxley.

Schultz, J. J., Johnson, D. A., Morris, D., \& Dyrnes, S. (1993). An Investigation of the Reporting of Questionable Acts in an International Setting. Journal of Accounting Research, 75-103.

Setiawan, M. A., \& Helmayunita, N. (2017). Pengaruh Pengendalian Internal, Tekanan Finansial, dan Moralitas Individu Terhadap Kecenderungan Kecurangan Akuntansi: Studi Eksperimen pada Konteks Pemerintahan Daerah. Economac:Jurnal Ilmiah Ilmu Ekonomi , 52-67.

Siaran Pers. (2011). Opini WTP Tidak Menjamin Tidak Ada Korupsi. Jakarta: Badan Pemeriksa Keuangan.

Tuanakotta, T. M. (2010). Akuntansi Forensik dan Audit Investigatif. Jakarta: Salemba Empat.

Undang-Undang Nomor 13 Tahun 2006. (2006). Perlindungan Saksi dan Korban. Jakarta: Lembaran Negara Republik Indonesia Tahun 2006 Nomor 64.

Undang-Undang Nomor 30 Tahun 2002. (2002). Komisi Pemberantasan Tindak Pidana Korupsi. Jakarta: Lembaran Negara Republik Indonesia Tahun 2002 Nomor 137.

Widarjono, A. (2010). Analisis Statistika Multivatiat Terapan. Yogyakarta: STIM YKPN.

Winardi, R. D. (2013). The Influence of Individual and Situational Factors on Lower-Level Civil Servants' Whistle-Blowing Intention in Indonesia. Journal of Indonesian Economy and Business , 361-376.

Xu, Y., \& Ziegenfuss, D. E. (2008). Reward Systems, Moral Reasoning, and Internal Auditors Reporting Wrongdoing. Journal Business Psychology, 323-331. 